\title{
THE SPENDING PATTERNS OF THE OLD-AGE PENSION BY THE FRAIL ELDERLY
}

\section{Herman Strydom, Corinne Strydom}

\section{INTRODUCTION}

A specific old-age home in a semi-urban area of South Africa delivers certain community outreach services besides the services to the inmates of the old-age home. A team of registered nurses have been delivering these home-care services since 2002, including physical care, a meal service and a transport service to clinics and hospitals. The profile of the elderly persons living in this specific community shows that they are mostly women, black and very poor. While rendering services to the aged persons in the community, staff members realised that especially the frail aged have very little finances to spend on their own keeping, although they all receive an old-age pension. This raised the question of possible neglect and financial abuse by their caregivers and other people, which in turn led to this specific research project. This article reports on an attempt to investigate the housing circumstances and the financial position of the participants, as well as determining whether they could account for their expenditure, the items that the pension was spent on, the point of payment of the pension, the accompanying person and the manner in which withdrawal of money took place. Furthermore, the investigation included whether participants cared for children, topics of interest for grandparents caring for children, and the physical appearance of participants.

\section{PROBLEM STATEMENT}

The number of elderly persons is increasing, even in the developing countries, and it can be expected that the elderly population will become even older. The elderly population is not only the fastest growing segment of society, but they are also an important part of the economy (United States Department of Justice, 2006:1). The overwhelming majority of South African elderly persons receive a state old-age pension, and because of major poverty and joblessness in South Africa, many elderly persons are the only individuals in a household who receive any income whatsoever and often have to support a number of people. This situation can lead to the abuse of the elderly person's pension.

Society undervalues, abuses and discriminates against elderly people, usually because of their devalued role as mostly receivers, and not contributors, of benefits to society (Dyer \& Rowe, 1999:163) and they are vulnerable to victimisation by crime (Zastrow, 2008:461). Voices are heard from various sources for investigations into ways of protecting the old-age pension of the elderly, and especially that of the frail elderly, in order for it to be invested in their favour and not be mismanaged by caregivers and other people.

It is general knowledge that many fraudulent activities have been going on in the South African pension system and that certain measures have been introduced to combat fraud. Du Toit (2007:4) points out that, since the Department of Social Development introduced measures to combat fraud in the system, more than 130000 people have been removed from the system and 2500 prosecuted. Furthermore, it is often found that the elderly experience harsh and unfriendly treatment from officials and that members of staff responsible for pension administration lack the necessary skills, and that fraud and corruption are prevalent (Van Zyl, 2003:112). 
It is also important to investigate the circumstances at pension pay points where the aged have to wait in long queues and occasionally have to return only the following day. It is frequently found that the provincial governments are unable to administer the pension scheme and to ensure timely and correct payouts of benefits (Van Zyl, 2003:112). Adequate provision should be made for security, shelter, water, toilets and comfortable seating at the pension pay points in order to improve the circumstances under which the aged receive their pensions. A request to this effect was also addressed to the North-West Department of Social Development (Peete, 2006:6). The elderly often need to travel long distances to these pay points; thus attempts should be made to accommodate them closer to home. The application process for pensions is an extremely difficult one for the aged and should be speeded up and streamlined (Peete, 2006:6).

Many of the elderly, and especially the frail elderly in the community, cannot explain what becomes of their monthly pension. The staff members at the institution who deliver certain services to the aged in the community have for some time felt the need to investigate this phenomenon of possible financial abuse of the elderly under their supervision. Many sources, among others the organisation Age in Action, have expressed the need for such investigations. The following research questions for this study can thus be formulated:

- How, and on what, do the elderly, and especially the frail aged, spend their monthly pension?

- Is there proof of financial abuse of the elderly by caregivers and other people?

- Can feasible suggestions be made to ensure that the pensions of the elderly, and especially the frail aged, be spent to their advantage?

\section{AIM AND OBJECTIVES OF THE STUDY}

The aim of this study is to investigate the spending patterns of the aged, and especially the frail aged, of their monthly pension, to ascertain whether financial abuse of the elderly does indeed take place and to make suggestions for spending pensions to the advantage of the aged.

This overarching aim will be supported by the following objectives:

- To ascertain how and what the pensions of the aged, and especially the frail aged, are spent on,

- To ascertain whether financial abuse of these elderly persons are indeed taking place, and

- To make suggestions that can be used to make sure that the pensions of elderly persons are indeed spent to their advantage.

\section{DEFINITION OF TERMINOLOGY}

\section{Elderly}

Although there is no universal definition of when one can be considered to be elderly, 60 or 65 years of age is normally regarded as the onset of old age (Sellas \& Krouse, 2006:5). In South Africa women receive an old-age pension at the age of 60 and men at 65 (New Dictionary of Social Work, 1995:3; Peete, 2006:6). Barker (2003:12; 139) considers the terms "elderly" and "aged" to be synonymous. Sixty-five years of age and older will hence be accepted as the definition of the elderly for purposes of this study. 


\section{Frail elderly}

Barker (2003:168) considers the frail elderly to be "Older men and women who suffer from or are vulnerable to physical or emotional impairments and require some care because they have limited ability or opportunity to provide entirely for their own needs." This definition is also in agreement with the definition of frail elderly that this specific old age home adheres to. The term 'frail elderly' thus refers to persons over 65 years of age who are physically and psychosocially not capable of caring for themselves and are reliant on others for their everyday functioning, including their finances (Gillin, 2002:1).

\section{Elder abuse}

The dimensions of abuse are important, such as the severity of the abuse, its frequency, its intentionality, its intimacy and its duration over time. What seems clear is that abuse occurs in a relational context and that there are different kinds of abuse (McCreadie \& Tinker, 1993:6566). Elder abuse can be considered to be mistreatment of elderly people and includes all the forms of abuse such as physical, sexual, financial, neglect, self-neglect and psycho-social abuse (Barker, 2003:139; Department of Social Development, 2003:15). The frail elderly are especially prone to abuse because of reduced cognitive or emotional functioning, and their need for continuous assistance with daily functioning (Vierthaler, 2004:2-3). Elder abuse is therefore an overarching term to include all kinds of abuse of elderly persons by any person involved in caring for the aged person in one way or another.

\section{Financial abuse}

Financial abuse can be seen as misuse, mismanagement, deprivation, extortion, duress, fraudulent activities or stealing of an elderly person's money, possessions, bank accounts or assets for personal gain by family members and others (Big Sky Prevention of Elder Abuse Program, 2006:2; Department of Social Development, 2003:15; National Committee for the Prevention of Elder Abuse, 2003:1-4). According to the Government Gazette (2007:13), economic abuse can also mean the disposal of household effects or other property that belongs to the older person without the older person's consent. Occasionally people are coerced into changing their will or signing over power of attorney (Cupitt, 1997:25; Sellas \& Krouse, 2006:4; the National Coalition Against Domestic Violence, 2006:1).

Another aspect of financial abuse is when the victim is deceived with the promise of goods, services or other benefits that are non-existent or never intended to be provided (Montaldo, 2006:1). Eckley and Vilakazi (1995:177) see these acts as the illegal and unethical exploitation of, or damage to, anything that belongs to an elderly person. Financial abuse can thus be considered to be any action taken by caregivers or other persons who violate or infringe on the possessions, including the finances, of an elderly person. Taking the scope of financial abuse into consideration, it is not strange that the United States Department of Justice (2006:1) estimates that nearly one third of all elder abuse cases involved financial exploitation.

\section{HYPOTHESIS}

Many aged persons, and especially the frail aged, are financially abused and prohibited from spending their pensions to their own advantage in order to provide for their personal needs. 


\section{RESEARCH METHODOLOGY}

The manager of this particular old-age home contacted the researchers and discussed the possibilities of a study of this nature. As a first step, the written permission of the programme manager of the Department of Social Development of the North-West Province had to be obtained before the project could even be initiated. After this basic permission to continue with the study had been obtained, the research proposal and other details of the study could be put in place. This study is based on a combination and integration of a literature review and an empirical study. Since not much work has been done on this topic and conceptual guidelines are basically absent, an exploratory design was used (Babbie \& Mouton, 2001:79-80; Friedman, 1998:39). After consideration of all options, it was decided that survey research would be the best option and specifically interviewing in accordance with a semi-structured schedule (Greeff, 2005:297; Welman, Kruger \& Mitchell, 2005:166-167).

The first draft of the schedule was constructed by the researchers after careful consideration of other more or less similar schedules. Data collection was done in the form of numbers, thus the quantitative paradigm was adopted (Neuman, 2003:35). It was decided to give fourth-year social work students exposure to research in the field, and every student had to participate in the study. The students were asked for their inputs in the second draft of the schedule.

Once the measuring instrument was finalised, students were trained as field workers and they had to practise on one another to complete schedules and to make sure they understood each question, that the schedule measured what it was supposed to measure, and that it repeatedly measured the same thing under the same circumstances. In this manner the validity and reliability of the measuring instrument could be determined (Babbie, 2004:141-146; De Vaus, 2002:27-31).

Currently 330 frail aged persons living in the community receive services from this particular old-age home. From the table in Stoker (1985) it was ascertained that $30 \%$ of the population, thus approximately 100 participants, could be utilised as a sample. It was decided to use systematic sampling by selecting every third name on an alphabetical name list of the population (De Vos et al., 2005:200). The fourth-year social work class of 2006 consisted of 20 students, which meant that every student was called upon to conduct five interviews, giving a total of 100 respondents. The schedule also made provision for translation into an indigenous language in order to gain the maximum inputs from participants. Some of the students had a good to excellent command of some indigenous languages, which was not an essential requirement but an additional bonus. The regular caregivers of these frail aged persons in the employ of the institution introduced the students to the participants. The two main investigators of this study were also present on all occasions to see to the logistics of the study, such as checking on the correctness and completeness of the completed interview schedules.

Having submitted a research proposal, the research team obtained ethical permission from both the Department of Social Development, Potchefstroom and the Ethics Committee of the NorthWest University with permission number 06k15, to undertake this study. It was important that the participants be informed of the details of the intended study. Seeing that many of the participants were illiterate and hard of hearing, explaining the details of the study needed to be done repeatedly and very slowly. After this all participants had to sign letters of consent. Many participants could only draw an X instead of signing, but it was essential that informed consent had to be given by each and every participant (Marlow, 2005:153-156; Strydom, 2005:59-60). 
Doing so ensured that participation in the study was voluntary and they could withdraw at any stage during the course of the study.

Other ethical issues that were taken into consideration were, among others, the prevention of harm to participants due to the possible sensitivity of some questions, for instance, concerning income and the way it is spent (Babbie, 2004:470-481). Because of the involvement of students, supervisors and official caregivers, extreme caution had to be taken to ensure anonymity and confidentiality for all data and to take the privacy of participants into account on all occasions. This principle was also communicated to all participants during the preparatory interview (Grinnell, 2001:65-66; Neuman, 2003:126-129).

\section{FINDINGS}

\section{Housing of participants}

Of the total number of participants, $66 \%$ mentioned that the house and stand are registered in their name, while the other $34 \%$ participants indicated that the house and stand do not belong to them. In Table 1 shows the total number of inhabitants of the houses of participants.

TABLE 1

NUMBER OF INHABITANTS PER HOUSEHOLD

\begin{tabular}{|l|c|}
\hline Age group & Number \\
\hline Children under 6 & 49 \\
\hline Children 7-12 & 61 \\
\hline Children 13-18 & 76 \\
\hline Adults with family ties & 249 \\
\hline Adults without family ties & 44 \\
\hline Aged respondents & 100 \\
\hline Total & 579 \\
\hline
\end{tabular}

According to Table 1, there is a mean number of 6 inhabitants per household. Only 5 participants indicated that they live alone in their house, while another participant mentioned a daughter and her baby living with her. Yet another participant mentioned a separate flat on her stand in which three of her children live. Table 2 gives the number of rooms of the household.

TABLE 2

NUMBER OF ROOMS PER HOUSEHOLD

\begin{tabular}{|c|c|}
\hline Number of rooms & Respondents \\
\hline 1 & 6 \\
\hline 2 & 17 \\
\hline 3 & 16 \\
\hline 4 & 36 \\
\hline 5 & 6 \\
\hline 6 & 3 \\
\hline 7 & 15 \\
\hline 8 & 1 \\
\hline Total & 100 \\
\hline
\end{tabular}


It is clear from Table 2 that the largest number of participants $(36 \%)$ live in 4-room dwellings, while $17 \%$ live in $2-, 16 \%$ in 3 - and $15 \%$ in 7 -room dwellings. The mean number of rooms per dwelling is slightly less than 4, namely 3,93. Table 3 indicates the number of bedrooms per household.

TABLE 3

NUMBER OF BEDROOMS PER HOUSEHOLD

\begin{tabular}{|c|c|}
\hline Number of bedrooms & Respondents \\
\hline 1 & 26 \\
\hline 2 & 51 \\
\hline 3 & 16 \\
\hline 4 & 7 \\
\hline Total & 100 \\
\hline
\end{tabular}

From Table 3 it is evident that the largest number of participants (51\%) live in 2-bedroom dwellings, while $26 \%$ live in 1 - and $16 \%$ in 3-bedroom dwellings. The mean number of bedrooms per household is slightly more than 2 , namely 2,04. If taken into consideration that the households have a mean number of 6 inhabitants, it can be deduced that more or less 3 people share a bedroom. In many cases overcrowding can thus not be ruled out.

\section{Financial position of participants}

As far as monthly income is concerned, all the respondents receive an old-age pension of R870 (approximately 120 US Dollars) per month. In the case of $48 \%$, the participants' pensions were the only income of the household. Of the total number of 393 adults living in these households, one receives a foster-care allowance, while 16 receive a child-care grant for the children in their care. One person receives four child-care grants for four children in her care. Of the remaining 375 inhabitants, only 38 have a permanent income, while 20 receive a subsistence grant. The salaries of the people who do have an income are between R300 and R2 000 per month, with a mean income of R800. It can thus be deduced that the overwhelming majority of inhabitants are dependent on the aged person's pension. Hence one can state that the participants in this study are very poor, since they have to live on their pension income and also, in most cases, share it with a couple of other people.

\section{Accounting for their expenditure}

Overall, $73 \%$ of the participants were of opinion that they could give an accurate account of the spending of their pension, while $19 \%$ could not, with $8 \%$ participants being uncertain. Because of the sensitive nature of the topic of expenditure and their being afraid that they would get into trouble or bring their caregivers into trouble, one can expect the number of negative and uncertain answers to be even larger. Elders are likely to hide abuse because of shame, humiliation and fear of retaliation (Malks et al., 2003:57). Table 4 shows the items that the pensions are spent on. 
TABLE 4

THE OUTLAY OF THE PAY POINT

\begin{tabular}{|l|c|c|c|c|}
\hline Item & Yes & No & Range of Amount & Mean amount \\
\hline House rent & 66 & 34 & R40-R450 & R155 \\
\hline Funeral policy & 67 & 33 & R35-R220 & R96 \\
\hline Payment to caregiver & 4 & 96 & R20-R400 & R185 \\
\hline Food & 90 & 10 & R100-R600 & R289 \\
\hline Medicine & 31 & 69 & R30-R200 & R93 \\
\hline Municipal account & 51 & 49 & R50-R500 & R131 \\
\hline Child care & 14 & 86 & R60-R300 & R153 \\
\hline Debt & 33 & 67 & R60-R2500 & R273 \\
\hline Transport & 68 & 32 & R40-R200 & R66 \\
\hline
\end{tabular}

Food is the item on which most participants (90\%) spend the largest percentage of their income (R289), which is quite understandable. Transport (68\%), funeral policy (67\%) and house rent (66\%) are also paid for by a large number of participants. Child care (14\%) and payment to caregiver (4\%) are the items only a few participants spend money on. One would expect more frail elderly persons to spend money on caregivers. This phenomenon can probably be attributed to the fact that most of the participants are cared for by a caregiver free of charge. It could also be expected that more than $31 \%$ participants would spend money on medicine. This can, however, be explained by that fact that people who receive an old-age pension also receive free medication from the clinic. The participants who thus spend money on medicine are those who need additional medicine which is not distributed by the clinics, or those who pay for medicine prescribed by a private doctor.

Only 33\% of participants admitted to having debt of between R60 and R2 500. It can also be noted that, on average, house rent (R155), municipal account (R131), funeral policy (R96) and transport (R66) take up a large percentage of the monthly income. If the total average expenditure is taken into account, it is obvious that it is much more than the amount of the oldage pension. This means that the participants do have an additional income from perhaps their children or other people. Table 5 indicates the place where the pension is paid out.

\section{Place where pension is paid out}

TABLE 5

PLACE OF PAYMENT

\begin{tabular}{|l|c|}
\hline Place of payment & Respondents \\
\hline Pension pay point & 31 \\
\hline Directly into bank account & 39 \\
\hline Post office & 30 \\
\hline Total & 100 \\
\hline
\end{tabular}

It is interesting to note that the largest group of participants (39\%) have the payment done directly into their bank account, while $30 \%$ use the post office. If calculated together, it is obvious that most of the participants (69\%) use direct payments into a bank or post office 
account. However, more than $30 \%$ of the aged persons still do not trust these kinds of payment and prefer the traditional way of receiving the pension, namely in person or by an assigned person at the pension pay point. A percentage of 36 assigned persons have authority granted by the aged person to withdraw the old-age pension on their behalf. Of the $36 \%$ assigned persons who draw the pension on behalf of the elderly person, it is reported that $69 \%$ live in the same household as the participant and that only $31 \%$ live at a different address than that of the participant.

\section{Accompanying person to pay point}

Of the $31 \%$ participants in the study who prefer to receive their money at the pension pay point, $45 \%$ have an assigned person to draw the money on their behalf. The other $55 \%$ are mostly accompanied by the following persons.

TABLE 6

PERSON ACCOMPANYING THE AGED PERSON TO THE PAY POINT

\begin{tabular}{|l|c|}
\hline Accompanying person & Respondents \\
\hline Marriage partner & 2 \\
\hline Own child & 7 \\
\hline Step child & 1 \\
\hline In-law child & 2 \\
\hline Grandchild & 1 \\
\hline Friend & 2 \\
\hline Other family member & 2 \\
\hline Total & 17 \\
\hline
\end{tabular}

Most of these $55 \%$ participants are accompanied to the pension pay point by their own child (41\%), followed by a marriage partner (12\%), an in-law child (12\%), friends (12\%) or other family members (12\%). Table 7 focuses on the manner in which withdrawal from the bank or post office account takes place.

\section{Manner in which withdrawal from account takes place}

TABLE 7

WITHDRAWAL FROM ACCOUNT

\begin{tabular}{|l|c|}
\hline Manner of withdrawal & Respondents \\
\hline By ATM card & 13 \\
\hline Inside bank/post office & 56 \\
\hline Total & 69 \\
\hline
\end{tabular}

Of the $69 \%$ participants who have the old-age pension paid directly into a bank or post office account, $32 \%$ use an assigned person to withdraw the money on their behalf. It can be deduced that $81 \%$ draw their money (self or by assignee) by completed slip inside the bank or post office. The fact that only $19 \%$ participants or assignees use an ATM card outside the bank can be an indication that they do not trust the new technology, or that they feel vulnerable and can easily fall pray to criminals. 


\section{Physical appearance of participants}

In this category the field workers had to answer definitely yes, yes, no and definitely no to whether the aged participant left the impression of being neat, fed and well cared for.

\section{TABLE 8}

THE PHYSICAL IMPRESSION OF PARTICIPANTS

\begin{tabular}{|l|c|}
\hline Impression: neat, fed, well cared for & Participants \\
\hline Definitely yes & 24 \\
\hline Yes & 26 \\
\hline No & 36 \\
\hline Definitely no & 14 \\
\hline Total & 100 \\
\hline
\end{tabular}

Twenty-four percent of the participants left the impression of being well cared for and of being neat, while $26 \%$ looked fairly neat, $36 \%$ did not look neat and $14 \%$ were clearly neglected. It is interesting to note that half the participants did not leave a neat and cared for impression, and were even neglected in some cases.

\section{Participants taking care of children}

Twenty percent of the participants indicated that they have children in their permanent care. When asked about their interest in an empowerment group for grandparents caring for children, $70 \%$ of these participants indicated interest in becoming a member of such a group. This was excellent, because to be part of an empowerment group would also strengthen participants against abuse. In Table 9 the interest in specific topics is indicated.

\section{Topics of interest for grandparents}

TABLE 9

TOPICS FOR GROUP DISCUSSIONS

\begin{tabular}{|l|c|c|c|}
\hline Topics & Yes & No & Total \\
\hline Discipline & 11 & 3 & 14 \\
\hline AIDS-preventative information & 7 & 7 & 14 \\
\hline Sexual matters & 8 & 6 & 14 \\
\hline Personal hygiene & 4 & 10 & 14 \\
\hline Financial matters & 6 & 8 & 14 \\
\hline Future planning & 9 & 5 & 14 \\
\hline Life skills training & 6 & 8 & 14 \\
\hline
\end{tabular}

Participants indicated their interest in certain topics and had to answer yes or no to each category. The main problems these elderly persons apparently experienced regarding these children were lack of discipline (79\%), the future planning of these children $(64 \%)$, sexual matters (57\%) and AIDS-preventative information (50\%). 


\section{DISCUSSION}

It was found that the elderly in this study live in circumstances of more or less 6 persons per 2bedroom household, which means 3 persons per bedroom on average. For privacy and a decent life this can be regarded as too many persons per room. Approximately $30 \%$ of the participants could not account for their monthly expenditure, which can point towards abuse, while more than $30 \%$ still prefer to receive their pension at the pension pay point. Half this number have an assigned person who draws the money on their behalf. An assigned person is mostly a family member, including sons, daughters, grandchildren, or spouses (National Committee for the Prevention of Elder Abuse, 2003:1). About a third of the participants who obtain their pensions from the bank or post office make use of an assigned person. The role and selection of an assigned person should receive careful consideration.

Twenty percent of the participants indicated that they have young children in their permanent care, which places a tremendous burden on these older persons on all levels of functioning. In more than $30 \%$ of the cases financial problems were evident due to the fact that there was no food in the home, the home smelled of urine and filth, dirty laundry and bed linen were evident, and windows were without curtains. Half the participants did not leave a neat and cared-for impression and even showed signs of being neglected. The participants complained of a variety of physical ailments and that the income was too small to survive on. Many said that children and grandchildren only visit them on pension days and for the rest they never see them. Others mentioned that the entire family lives on their income and that they become annoyed if they are refused money. Financial abuse can thus be expected in many cases, but the elderly do not admit this and try to cover it up.

An escalating threat of financial abuse among the elderly population was evident in this study and frail elderly persons are especially vulnerable to abuse. The literature confirms abuse of the elderly, procedures are in place for dealing with cases of abuse and the perpetrators (Department of Social Development, 2006:24-32), and yet few cases are prosecuted. This can be attributed to the fact that elder abuse is a complex and highly emotional issue that is increasing in a worldwide context (Strydom, 2003:76-77). There is a generally low awareness of elder abuse among the elderly and the general public, and the aged do not always know their right to report these cases. Service centres can be regarded as places in the community that are in a position to offer a variety of multi-professional services to the elderly, such as social work services, meal services and nursing services. These facilities in the community are by and large meant to coordinate all the services to the elderly in that particular community. Structural changes in society such as working women and looser family ties resulted in few families still caring for their aged relatives in the traditional manner.

The components of a proactive community systems approach include local needs assessment sensitive to the cultural needs of an area, the identification of service providers and the facilitation of access between service providers and seniors (Schuyler \& Liang, 2006:2). The term 'adult protective services' or APS refers to publicly funded programmes that investigate and intervene in cases of abuse and exploitation of elders who are physically or mentally impaired, and unable to protect themselves from harm (Mixson, 1995:69). The Israeli supportive community programme is based on two assumptions, namely that most of the elderly population prefer to live in their own homes as long as their quality of life can be maintained, and that provision of community services is less expensive than institutional care (Auslander et al., 2003:209). 


\section{RECOMMENDATIONS}

The importance of the family structure should once again be realised and these relationships strengthened. Aged persons should receive preventative and rehabilitative health care besides normal health care support and social protection (Second World Assembly on Ageing, 2002:2).

Strydom (2003:94) recommends that respect for the elderly should be re-instilled in communities and that elderly persons be seen for what they are and what they can still contribute to society at large. Ageism must be addressed in society, as well as abuse in all its forms. The United Nations Economic and Social Council (2005:4) also made a plea for fair globalisation by creating opportunities for all aged persons in the world. In order to achieve such a positive attitude, atmosphere and opportunities for the aged, the whole community should be mobilised.

A proactive community approach to care for the elderly in all its facets, including dealing with elder abuse, should be instilled in which the community of elderly persons is made aware of their rights as citizens and enabled to act as a group in cases of violation of their rights. The public should become involved in practical ways to care for the elderly and to combat abuse for instance coffee mornings with a guest speaker and a discussion on any issues pertaining to the elderly population. Another suggestion is a "big brother day" for the elderly, where mentors are selected for the elderly (International Network for the Prevention of Elder Abuse, 2006:9).

Community members can act as speakers, and training videos, group exercises and discussions can be used to facilitate these events. Even kind supportive words of encouragement and referrals provide options and support for the elderly (Spangler \& Brandl, 2007:328). In this way elderly persons at risk of being abused can be identified and preventative programmes in communities can thus be installed (National Center on Elder Abuse, 2007:1). The role of service centres and luncheon clubs for the aged should take the lead in these programmes.

Elderly persons should be empowered with knowledge to be able to report abuse and not to fear perpetrators and possible retaliation. Elderly persons should know of the possible ways in which their abuse can be reported and treated, even if they do not wish the perpetrator to be prosecuted at first. Service centres and luncheon clubs for the aged should play a more active role in this regard.

When in contact with abused elderly persons or elderly persons where abuse is suspected, some practical issues demand attention, such as ending the isolation of the person (Strydom, 2003:89-94), cheques being directly deposited into the person's account, making reference checks on the criminal record of the caregiver, limiting the power of attorney, keeping communication going with the bank officials and keeping people involved in the life circumstances of the elderly person (Idaho Careline, 2007:1-2).

A series of workshops can be developed for professionals already providing services to the elderly in the community, for instance, further identification and assessment of cases of elder abuse, development and implementation of intervention strategies, and exploration of ethical dilemmas and problem-solving strategies (Weiner, 1991:114).

Service centres for the aged, and specifically their multi-professional teams, must be involved in assisting abused persons but also to establish preventative programmes. Service centres and their staff members are responsible for all the services being offered, such as a distress button which is connected by intercom and telephone, medical services, social work services and a social programme (Auslander et al., 2003:209-210). Social workers and nursing staff are the 
first line of workers who come into contact with abuse of the elderly, and a multi-disciplinary approach to victim support should be followed at all times. These professionals are trained to be on the look out for signs of abuse such as isolated elderly persons, elderly persons who avoid the topic of abuse, or caregivers who do not allow the aged to talk to the professional in private.

Government should support research endeavours to determine criteria for deciding on the risk factors for each and every aged person as well as to gain scientific criteria to be able to ascertain when and how a person has been abused and what the criteria for care giving should be.

Measures should be developed to combat elder abuse, and stricter law-enforcement measures should be advocated and introduced. Professionals should familiarise themselves with the guidelines for the protection of older persons in the Older Persons Act (Department of Social Development, 2003:24-32) and should be able to apply it in practice.

It can thus be concluded that, although not much overt abuse was discovered in this study, much more is taking place and that many aged persons are suffering in silence for many reasons such as not knowing their rights, fearing retaliation and feeling sorry for the perpetrator.

\section{SUMMARY}

This study was done in a semi-urban area of South Africa, where certain community outreach services have been delivered for some time. This specific programme is facilitated by an oldage home in the vicinity of this community and the services are rendered by a number of registered nurses and volunteers. For some time now the service providers have realised that the elderly in their care have very few financial means for themselves. They became aware of possible abuse and hence the study was initiated. In this study the financial position of the participants was investigated with an emphasis on the housing circumstances, whether they could account for the spending of their income, the items the pension was spent on, the point of payment of the pension, the accompanying person and the manner in which the withdrawal of money took place. Caring for children, topics of interest for grandparents caring for grandchildren, physical appearance of participants, and some observations and remarks by field workers were also addressed in this article.

\section{BIBLIOGRAPHY}

AUSLANDER, G.K., SOFFER, M. \& AUSLANDER, B.A. 2003. The supportive community: help seeking and service use among elderly people in Jerusalem. Social Work Research, 27(4):209-221.

BABBIE, E. 2004. The practice of social research. London: Thomson Wadsworth.

BABBIE, E \& MOUTON, J. 2001. The practice of social research. Cape Town: Oxford University Press.

BARKER, R.L. 2003. The social work dictionary. Washington: National Association of Social Workers.

BIG SKY PREVENTION OF ELDER ABUSE PROGRAM. 2006. What is elder abuse? Available: http://www.mtelderabuseprevention.org/whatis.html. [Accessed: 28/01/2007]. 
CUPITT, M. 1997. Identifying and addressing the issue of elder abuse: a rural perspective. Journal of Elder Abuse \& Neglect, 8(4):21-30.

DEPARTMENT OF SOCIAL DEVELOPMENT. 2003. Older Persons Bill. Pretoria: Government Printers.

DEPARTMENT OF SOCIAL DEVELOPMENT. 2006. Older persons Act, Nr 13 of 2006. Pretoria: Government Printers.

DE VAUS, D. 2002. Research design in social research. London: SAGE Publications.

DE VOS, A.S., STRYDOM, H., FOUCHÉ, C.B. \& DELPORT, C.S.L. 2005. Research at grass roots: for the social sciences and human service professions. Pretoria: Van Schaik Publishers.

DU TOIT, P. 2007. "Korrupsiestryd hupstoot vir die toelaes." [Corruption struggle boosts pensions.] Beeld, 4: 22 Feb.

DYER, C. \& ROWE, J. 1999. Elder abuse. Trauma, 1:163-169.

ECKLEY, S.C.A. \& VILAKAZI, P.A.C. 1995. Elder abuse in South Africa. Journal of Elder Abuse and Neglect, 6(3/4):171-182.

FRIEDMAN, B.D. 1998. The research tool kid: putting it all together. London: Brooks/Cole Publishing Company.

GILLIN, E. 2002. Financial abuse of the elderly. Available: http://www.thestreet.com/ funds/ericgillin/10023597.html. [Accessed: 31/01/2008].

GOVERNMENT GAZETTE. 2007. Draft Regulations under the Older persons Act, nr 30408 of 2 Nov 2007. Pretoria: Government printers.

GREEFF, M. 2005. Information collection: interviewing. In: DE VOS, A.S., STRYDOM, H, FOUCHÉ, C.B. \& DELPORT, C.S.L. (eds) Research at grass roots: for the social sciences and human service professions. Pretoria: Van Schaik Publishers: 286-313.

GRINNELL, R.M. 2001. Social work research and evaluation: quantitative and qualitative approaches. New York: F.E. Peacock Publishers.

IDAHO CARELINE. 2007. Seniors and financial abuse? Available: http://www. idahocareline.org/eLibrary/Senior\%20Financial\%20Abuse.html. [Accessed: 22/02/2007].

INTERNATIONAL NETWORK FOR THE PREVENTION OF ELDER ABUSE. 2006. Bulletin: action on elder abuse: a colorful report. Toronto: INPEA head office, July/Aug.

MALKS, B., BUCKMASTER, J. \& CUNNINGHAM, L. 2003. Combating elder financial abuse: a multi-disciplinary approach to a growing problem. Journal of Elder Abuse and Neglect, 15(3/4):55-70.

MARLOW, C.R. 2005. Research methods for generalist social work. London: Thomson Brooks/Cole.

McCREADIE, C. \& TINKER, A. 1993. Review: abuse of elderly people in the domestic setting: a UK perspective. Age and Ageing, 22:65-69.

MIXSON, P.M. 1995. An adult protective services perspective. Journal of Elder Abuse and Neglect, 7(2/3):69-87. 
MONTALDO, C. 2006. Financial crimes against the elderly. Available: http://crime. about.com/od/elderabuse/a/fraud.htm. [Accessed: 25/01/2008].

NATIONAL CENTER ON ELDER ABUSE. 2007. Multidisciplinary and collaborative approaches in responding to elder abuse. Washington: NCEA Office.

NATIONAL COALITION AGAINST DOMESTIC VIOLENCE. 2006. Newsletter: abuse in later life. Washington: NCADV Public Policy Office.

NATIONAL COMMITTEE FOR THE PREVENTION OF ELDER ABUSE. 2003. Financial abuse. Available: http://www.preventelderabuse.org/elderabuse/fin abuse.html. [Accessed: 31/01/2008].

NEUMAN, W.L. 2003. Social research methods: qualitative and quantitative approaches. New York: Allyn and Bacon.

NEW DICTIONARY OF SOCIAL WORK. 1995. Terminology Committee for Social Work. Cape Town: CTP Book Printers.

PEETE, F. 2006. “133 officials up for social grant fraud.” Pretoria News: 6, 31 Mar.

SCHUYLER, D. \& LIANG, B. 2006. Reconceptualizing elder abuse: treating the disease of senior community exclusion. Annals of Health Law, 15:1-9.

SECOND WORLD ASSEMBLY ON AGEING. 2002. Madrid International Plan of Action on Ageing. Madrid, Apr.

SELLAS, M.I. \& KROUSE, L.H. 2006. “Elder abuse.” eMedicine. Available: http://www.emedicine.com/emerg/topic160.htm. [Accessed: 07/04/2006].

SPANGLER, D. \& BRANDL, B. 2007. Abuse in later life: power and control dynamics and a victim-centred response. Journal of the American Psychiatric Nurses Association, 12(6):322-331.

STOKER, D.J. 1985. Sampling - personal communication to the author. Pretoria: HSRC.

STRYDOM, H. 2003. Perceptions and attitudes towards elder abuse. The Social Work Practitioner-Researcher/Die Maatskaplikewerk-Navorser-Praktisyn, 15(1):76-96.

STRYDOM, H. 2005. Ethical aspects of research in the social sciences and human service professions. In: DE VOS, A.S., STRYDOM, H., FOUCHÉ, C.B. \& DELPORT, C.S.L. (eds) Research at grass roots: for the social sciences and human service professions. Pretoria: Van Schaik Publishers: 56-70.

UNITED NATIONS ECONOMIC AND SOCIAL COUNCIL. 2005. Commission on population and development, thirty-eighth session 4-8 Apr. New York: United Nations.

UNITES STATES DEPARTMENT OF JUSTICE. 2006. Financial crimes against the elderly. Available: http://www.cops.usdoj.gov/default.asp?Item=1047. [Accessed: 22/01/2008).

VAN ZYL, E. 2003. Old age pensions in South Africa. International Social Security Review, 56(3/4):101-120.

VIERTHALER, K. 2004. Elder sexual abuse: the dynamics of problem and community-based solutions. Newsletter of the National Center on Elder Abuse, 6(7):2-3.

WEINER, A. 1991. A community-based education model for identification and prevention of elder abuse. Journal of Gerontological Social Work, 16(3/4):107-119. 
WELMAN, J.C., KRUGER, F. \& MITCHELL, B. 2005. Research methodology. Cape Town: Oxford University Press.

ZASTROW, C. 2008. Introduction to social work and social welfare: empowering people. London: Thomson Brooks/Cole.

Prof Herman Strydom and Dr Corinne Strydom, School of Psycho-social Behavioural Sciences: Division Social Work, Potchefstroom Campus of the North-West University, Potchefstroom, South Africa. 